\title{
THE NECESSITY AND JUSTIFICATION OF REFORMS OF PUBLIC CORPORATIONS
}

\author{
Jokić Zoran, lecturer at \\ Higher Technological School of Professional Studies in Šabac \\ Sekulic Vesna, full professor, \\ Faculty of Economics, University of Nis
}

\begin{abstract}
Summary: In the present business environment, negative opinion on the work of the public sector prevails. According to the public opinion, one gets the impression that it is necessary to privatize the public corporations as soon as possible and this way get rid of this kind of ballast. Having in mind the negative effects of previous transitional period, it is necessary to approach this issue cautiously, so the process of the reforms would give optimal social benefits.
\end{abstract}

Key words: public corporation, reform, competition, monopoly, efficiency.

\section{Introduction}

Having in mind the importance and specificity of business environment, on the one hand, and the deregulation of the public corporations (PC) in the form of harmonization and liberalization, on the other hand, it is necessary to conduct the implementation of the reform of PC. Regardless of whether the reform of PC is conducted in terms of a competitive or monopolistic business environment, it must have the effect of raising the efficiency of PC. The essence of raising the efficiency of PC refers to the maximization of social wealth of the respective society.

\section{The business environment of public corporations}

The ruling economic doctrine holds that the mutual business interactions of people are primarily based on economic rationality, i.e. on the behavior of man as homo economicus (or economic man). Adam Smith, in his book "The Wealth of Nations" published in 1776, came to the conclusion that the economy can function well only when people are motivated solely by their own interests. When people are motivated by the desire to increase their wealth (i.e. to satisfy their different motives), then they will strive to be the best, that is the most efficient in comparison to their competitors. When an individual produces, he does not work out of love and kindness to man (at least not explicitly), but out of love for himself, his family, and just for the love of itself, the society can expect good for the entire community. In this struggle for themselves, if there are free and equal conditions for all, the best will succeed (competitive conditions). Thus achieving its own goals, the society will be richer and thus the whole society will achieve its goals, which in the derived sense means maximizing the level of social well-being of the society. Hence, by achieving individual benefits, the individual will increase the benefits for other people as well ${ }^{1}$. Representatives of neoliberal ideas were denied by the reality of the business, in the sense that serious problems appeared in the functioning of the modern market of the business environment. These problems have been recognized and publicly spoken about by many economic theoretician, including Nobel Prize winners in economics J.E. Stiglitz and P. Krugman ${ }^{2}$, and with the final conclusion that the state must, to some

\footnotetext{
${ }^{1}$ Customized according to section "Adam Smith and the invisible hand": N.G. Mankiw (2008), "Principles of Economics", Faculty of Economics, Belgrade, p. 10.

${ }^{2}$ There is a consensus among economists that the Government with its activities may contribute to improve the functioning of the respective economies. Disagreement among economists exists only in the extent under what conditions the Government should intervene. See more about this in books: Stigliz J.E. (2009), "The success of globalization (New Steps to a just world)," Algorithm Zagreb;
} 
extent, interfere in the business environment. Problems of inefficiency and imperfection of the market for which there must be a state intervention in the economy, according to J.E. Stiglitz-u are related to the following cases:

- "the emergence of monopolies,

- the occurrence of externalities,

- the existence of asymmetric information,

- the existence of incomplete / undeveloped markets,

- the necessity of public goods;

-the formation of macroeconomic disorder" 3 " and

- the phenomenon of moral hazard.

The formation of monopolistic business environment leads to various kinds of inefficiencies that only the state can effectively solve. Also, because of the presence of positive and negative externalities, the state must intervene in the sense that it promotes the positive and reduces the negative externalities. Furthermore, the country with its regulations must seek to minimize the negative effects that have arisen as negative consequences of asymmetric information actions. Markets which are not sufficiently developed will also have a negative consequence, i.e. the absence of certain outputs, and thus an unmet demand for the respective outputs, which will negatively affect the reduction of the welfare of the respective society. In circumstances when negative macroeconomic developments are created, the state can be a key factor in their elimination. And, finally, the phenomenon of moral hazard means that people in certain moments do things that are not in their interest or in the interest of other people. Because of this kind of behavior of

\footnotetext{
3 J.E. Stiglitz (2004), "Public Economics", Faculty of Economics, Belgrade, p.85.
}

individuals it is necessary for the state to take care of their interests ${ }^{4}$.

\section{Social responsibility of public corporations}

Interests of the country should not be based solely on economic interests because the government is not a company that needs to maximize profit, but it needs to take care of the development of the human personality by the principle of developing "individuals to social cognition" ${ }^{5}$. This is very important if we know that the overall economic growth and the economic development of the country is based on the people/individuals. Therefore, the state must take care of the needs of people both in the material and spiritual sense. What is the significance of the aforementioned claims can best be seen in the attitudes of the famous psychoanalyst Carl Gustav Jung: "People do not always behave rationally and they do not behave as it would be in their best interest."The rational man", on which so much economic theory is based on, at best, is only a partial description of human beings in terms of how they really function. People are driven by psychological forces, they are motivated by thoughts that are not based on rational processes, and are subject to performance and impacts that go beyond those which can be measured in the visible environment. In short, we are creatures that are driven by emotions and performance as much as we are rational and adapted to the environment. We dream as much as we think, and probably feel a lot more than we think. At the very least, many thoughts are colored and shaped with the help of emotions, and

\footnotetext{
${ }^{4}$ D. Kreps (1990), "Corporate Culture and economic Theory," in Alt, JA, Shepsle, K., 1990, PCrcPCctives on Positive Political Economy, Cambridge UK: Cambridge University Press, pp.90143.

S. PCltzman, (1975), "The Effects of Automobile Safety Regulation", Journal of Political Economy, 83, pp. 677-725.

${ }^{5}$ On the development of the human PCrson to see more in the book: A. Adler (2012), "Knowing the man," Dereta, Belgrade.
} 
most of our rational calculations are servants of our passions and fears"

If we add to the previously mentioned that many wise people throughout human civilization, like Socrates, Plato, Aristotle, Marcus Aurelius, Benedict Spinoza, Immanuel $\mathrm{Kant}^{7}, \ldots$ believed that man is not only homo economicus, but that man was given and affirmed and as such destined to be much more than the existing one, the aforementioned concept of neoliberalism cannot be seen as the ultimate goal, but only a way station in a man's ontological development. If the business behavior of people is based solely on the rationality which is reflected on maximizing the profit i.e. on maximizing the human greed, vanity and narcissism, and if it is known that greed, vanity and narcissism are flaws, it means that a man is going to work on maximizing the flaws. By increasing the flaws one cannot build a successful future of people, because the exclusive development of such a business environment will result in negative economic developments, such as the emergence of inflation, stagflation, slampflation, recession, social unrest, poverty, wars, diseases etc. Therefore, solely to maximize profit of individuals without a functioning government regulation will lead to such consequences that the market will not perform the efficient allocation of its limited resources. In other words, the maximum economic effect of the society in relation to the available resources will not be achieved. So, in individual cases, the state must interfere in the economy, in order to continuously increase the social well-being of the respective society. For these reasons, the state needs to have goals that will be much wider set in relation to the objectives that are tied exclusively to selfish interests of a small number of individuals.

\footnotetext{
6 M. Stein, (2007), "Jung's map of the soul," Laguna, Beograd, p.49

${ }^{7}$ See more about this in the book: Rađenović B, N. Rodic, Rađenović M., (2010), "Communication" high school of Technology, Šabac, p. 51-55.
}

Based on the aforementioned, there are the sufficient reasons according to which it can be concluded that it is necessary to have public corporations (i.e. state-owned enterprises) in the economic structure of the country. In order to make the existence of public corporations based on the principles of necessity, their existence must be justified. Thus, the work of public corporations must be based primarily on the maximum rationality of their operations, and this can be achieved by managing the performance of $\mathrm{PC}^{8}$.

\section{Reform of the activities of public corporations}

By only establishing/existence of public corporations, it does not mean that problems of market imperfection will be solved by themselves. On the contrary, due to the existence of numerous restrictions on the business operations of public corporations, state-owned enterprises alone can be a source of problems, not a means of solving the problem (this is covered extensively by M. Friedman ${ }^{9}$ ). For these reasons, it is necessary that public companies adhere to economic laws in its business activities.

Work of public companies in the Republic of Serbia (RS) was marked by multimillion-dollar losses, which have a constant trend of growth. The contribution of PC to the total debt of RS is also very significant. The public corporations in RS are characterized by the lack of funds for investment, investment inefficiency, conflict of economic and political interests, unprofessional management, inefficient business operations, inadequately determined vision and mission, the lack of capital, high amortization of the property, insufficient development of public infrastructure and the like. Based on the

\footnotetext{
${ }^{8}$ See more about this in the book: B. Krstić, Sekulić V., (2007), "Managing the performance of the company", Faculty of Economics, Niš.

${ }^{9}$ Friedman M., (1997.), „Capitalism and freedom“, Global, Novi Sad.
} 
established performance of public corporations in the Republic of Serbia, it can be concluded that the reform of public corporations work is necessary, and because of the importance / significance of the existence of public corporations, it is justified, too. Mere labor reform of PC can go in two directions: toward corporatization and / or in the direction of privatization of the work of PC. Prior to any privatization of PC it is necessary to undertake activities related to the process of corporatization of their business. Corporatization of business activities of PC essentially refers to the increase of freedom in decision-making and management of PC as well as in increasing its management responsibility for the results achieved. The mere corporatization is essentially the commercialization of PC business activities. The commercialization of PC business operations would enable directing all available resources of PC to their final users. We can talk about several phases, that is activities of the process of corporatization of PC, namely:

- "the activities of changing the legal form of public corporation,

- the activities of the fair treatment of the government for both public and private companies,

- increasing the level of social responsibility of public corporations,

- the activities of allocating non-core activities from the composition of PC,

- the activities of creating a new organizational structure of public corporations,

- the activities related to the elimination of numerous restrictions in the business operations of the $\mathrm{PC}$,

- the activities related to performance management of public corporations as well as their measurability and transparency. "10

10 Adapted from: Stigliz J.E. (2004), "Public Economics" Economic faculty, Belgrade, p. 208210

4
Changing the legal form of PC refers to formal and legal activities in terms of PC transformation into joint stock companies. In this way, PC would be in a position to get the missing capital cheaper and also to eliminate a number of restrictions in their work. An equitable treatment of private and public companies by the state will result in compelling the PC management to work more efficiently. Adopting a broader concept of social responsibility by PC, according to numerous stakeholders, will result in recognition of a wider range of interests that may even be contrary to the interests of PC. Separation of secondary activities from PC can be conducted, but only when the outputs of daughter companies of PC are more expensive than the outputs that the PC can get on the market. The new organizational structure, both vertically and horizontally, must bring guidance of the resources of PC, primarily to the end user, which will lead to increase of competitiveness in business. The application of economic laws in business operations by competent managers will lead to the elimination of numerous restrictions of PC, as well as raising the efficiency of $\mathrm{PC}$ in terms of successful planning, measuring, analyzing and taking actions to improve the results of work of PC.

According to Joseph E. Stiglitz, there are two main reasons that lead to inefficiency of business operations of public corporations and that are organizational and individual reasons. "Organizational reasons for the inefficiency of business operations arise from ability of PC to complete socialization of their losses due to the monopolistic position of $\mathrm{PC}$, due to a conflict of political and economic interests in the PC as well as due to the lack of investment funds in PC. Staff and bureaucratic constraints of PC work are

Vukotic M., (1995), "Modern Post", No. 1, JP PTT "Serbia" Belgrade, p. '18.;

Rakić B., (2007), "The restructuring of public corporations owned by the Republic of Serbia", Faculty of Economics, Niš, p. 163-173. 
together included in individual reasons of inefficiency of PC business ". ${ }^{11}$

Business operations of $\mathrm{PC}$ can be organized in a competitive and monopolistic business environment. Both market frameworks have their own characteristics that one must keep in mind when implementing the reform process.

\section{Public corporations in a competitive business environment}

In this context, the public corporation in its business operations must take into account the movement of its marginal cost, i.e. at which production volume will marginal cost equate to the average total costs of the

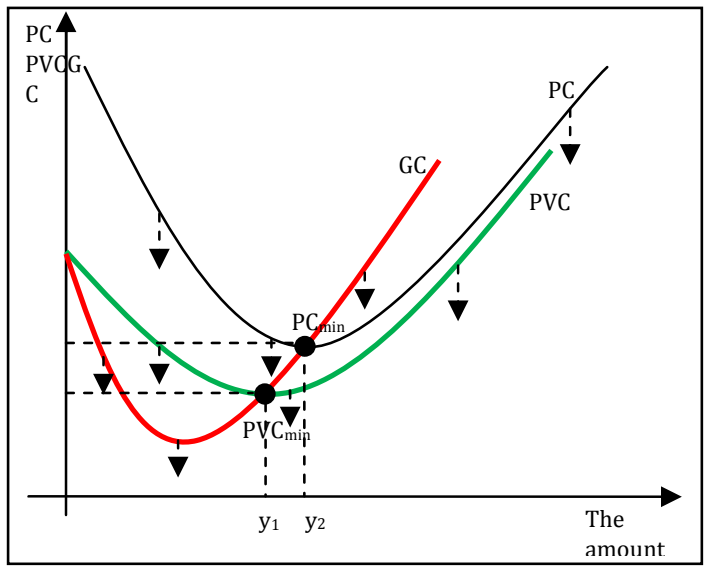

Figure 1: A strategy to reduce costs

respective public corporation. In the abovementioned point of identity, the minimum cost of producing an output of a public corporation is achieved. The achieved minimum of average total cost must be below or at the level of the given market price so that public corporation would not be in loss. If $\mathrm{PE}$, in the conditions of competition, can withstand a race in the efficiency and effectiveness with other manufacturers, then PE will not adversely

11 Adapted from: J.E. Stiglitz (2004), "Public Economics" Faculty of Economics, Belgrade, p. 202-207. affect the level of welfare of the state, and as such, it can survive in state ownership. If a public corporation cannot withstand the race, it should be privatized i.e.it should be replaced by a private company. During the privatization of a public corporation, which cannot operate at the level of positive or zero economic profit, state / government must analyze in detail, all the positive and negative effects of such privatization. The assessment or consequences of negative effects of privatization may occur in the following forms, namely: in reducing the number of employees in the privatized public corporation; in reducing salaries / demand in the relevant business environment; in the analysis of whether privatization is a big sale of rare national resources (national wealth); in the analysis of whether and how privatization of PC will impact on the safety and security of society, and the like. Based on the size of the negative and the positive results, state / government have to decide in which direction the PC reform should go, whether in the direction of corporatization and / or privatization or exclusively in the direction of privatization.

The competitive business environment in which PC operates, with elements of a perfect competition, will force the management of public corporation to achieve minimum costs of business operations if it wants to survive in the market. The minimum amount of the costs in the production of output that a public corporation should strive for in its business operations, is the equilibrium price at which a zero economic profit is achieved. Namely, a public corporation in the mentioned business environment together with other companies realizes a long-term market balance with all the positive effects on the level of welfare of the society. Characteristics of a long-run equilibrium (Figure 2), in conditions of a perfect competition, according to Gregory Mankiw are as follows: 


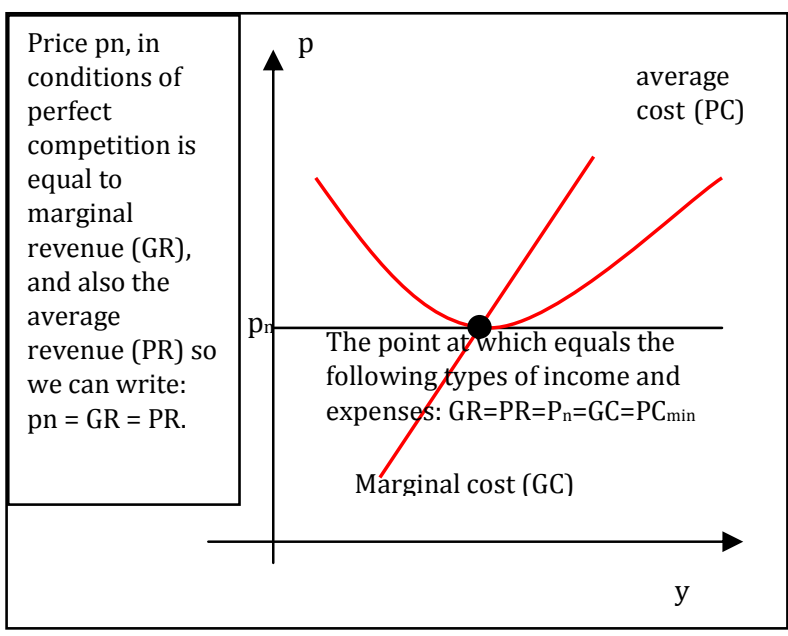

Figure 2.: Long-run equilibrium of $P C^{12}$

1) "The average costs of the business operations of a public corporation (PC) are equated with an average income (PR) of the public corporation i.e. the given price of the output. Because of this fact, zero economic profit is achieved as well as the loss of motives of the company to appear and enter the relevant economic sector;

2) By equality of the marginal revenue and the marginal cost of the public corporation the profits are maximized in the given circumstances (referring to the level of the accounting profit bearing in mind that economic profit is zero);

3) And, finally, the equality of the marginal costs and the average total cost of a public corporation means that the public corporation in the production of its outputs (goods and services) establishes minimum possible average total costs and in this way it maximizes production volume i.e. achieves the efficient scale of

12 Graphic displays are adapted to the HR Varian, "Microeconomics", Chapter 20 and Chapter 21, p. 399. production in the given circumstances. "13

In this way the level of welfare of the society is maximized, shown as the sum of consumer surplus and manufacturing surplus of a society.

If PC is working with losses, replacing the public corporations with private should go slowly and with monitoring the work of the $\mathrm{PC}$ in the short (corporatization) and a long time horizon (privatization or subsidization). The long and the short time horizon of the strategy of public companies must be focused on minimizing operating costs. PC in the conditions of competition must in the long time horizon implement a long term strategy of minimizing loss (Figure 3, under B), i.e. PC should organize the production of its outputs in the way that the average total costs could be covered with the production of the output. If this is impossible, a public corporation must stop producing the respective outputs or the government must privatize it. If the government deems that the PC must exist, in the circumstances of the achieved loss even then the public corporation should strive for maximum minimization of business operating costs by applying the concept of business performance management. In this way, the management of PC can reduce losses to a minimum, but the work of PC must be financed / subsidized by the government. When making decisions about subsidizing the work of PC, the government must be very careful and endeavor to make subsidizing based on the principles of the efficiency of taxation $^{14}$.

\footnotetext{
${ }^{13}$ Adapted from: Mankiw N.G., (2008), "Principles of Economics", Faculty of Economics, Belgrade, p. 305 also features of all signs customized according Mankiw N.G.

${ }^{14}$ See more about this in the book of HS Rosen, T. Gayer (2011) "Public Finance", Faculty of Economics, Belgrade, sixteenth head "Efficient and fair taxation, Ramsey's rule" p. 383-410.
} 


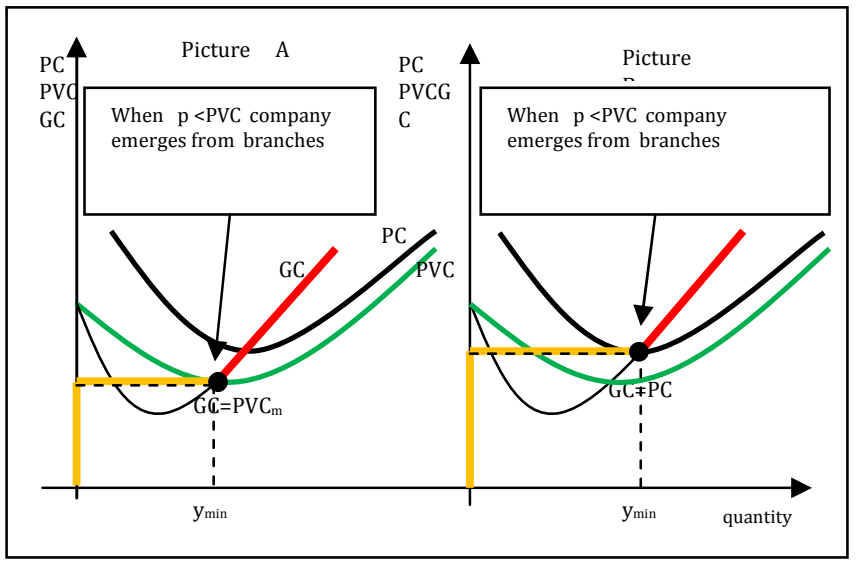

Figure 3: The formation of the demand curve of PC in short and long period ${ }^{15}$

The implementation of strategy of minimizing the costs in the short time horizon of the business operations of a public company can be performed by using the corporatization of business operations of the respective PC. Corporatization, i.e. commercialization of the business activities of PC should have as a consequence that the minimum average total costs of the output of PC is below or at the level of its output price (Figure 3, under A). When the price of the output of public corporation is between its average variable costs $(P V C)$ and average total costs $(P C)$, then the public corporation covers all variable costs and part of the fixed costs. In such circumstances, in a short period of time, the public corporation should through corporatization of its business operations undertake all activities which are necessary in order to achieve equality of prices and minimum average total costs, i.e. to come out of the loss zone. If even after the completed corporatization the $\mathrm{PC}$ is in the loss zone, the government must decide what to do with it (privatization or subsidization). In case when the price of the PC output is equal to its average variable costs, it is necessary that the state makes a decision regarding further production of the output in the PC, because in the current circumstances total fixed costs are not covered, but only variable costs are covered. And finally, the worst scenario is if the price of the PC output is below its average variable costs. Under such conditions (especially when the corporatization of the $\mathrm{PC}$ is carried out) double damage is achieved, because the total fixed cost and part of variable costs of the business operations of the PC are not covered. In these conditions, and also when the price is equal to the average variable costs, it is very likely that the damage is greater than the benefits of the nonmonetized work of PC, and thus it is a very high probability that the $\mathrm{PC}$ will be privatized or "go" into liquidation i.e. it will stop to exist.

\section{Public corporations in the monopoly business environment}

In most cases, public corporations are organized as monopolies. Companies as monopolies have certain limitations based on which they have the strength and draw their power to be able to affect, to a certain extent, on the price level and the quantity of output. Monopolistic environment according to Gregory Mankiw can be divided into three different types:

- When a PC possesses a rare / limited resource and on that basis it establishes its monopoly position;

- When a PC gets institutional protection by the government, and in such circumstances the legal monopoly public corporation is formed;

- When a PC is established for economies of scale and thus a natural monopoly was created i.e. the so-called network/ inevitable monopoly.

If it is a monopoly based on law or scarce resources, they have similar cost curves as opposed to natural monopolies (Figure 4).

15 Graphical presentations are adapted to the Mankiw N.G., (2008), "Principles of Economics", Faculty of Economics, Belgrade, p. 299 and 301. 


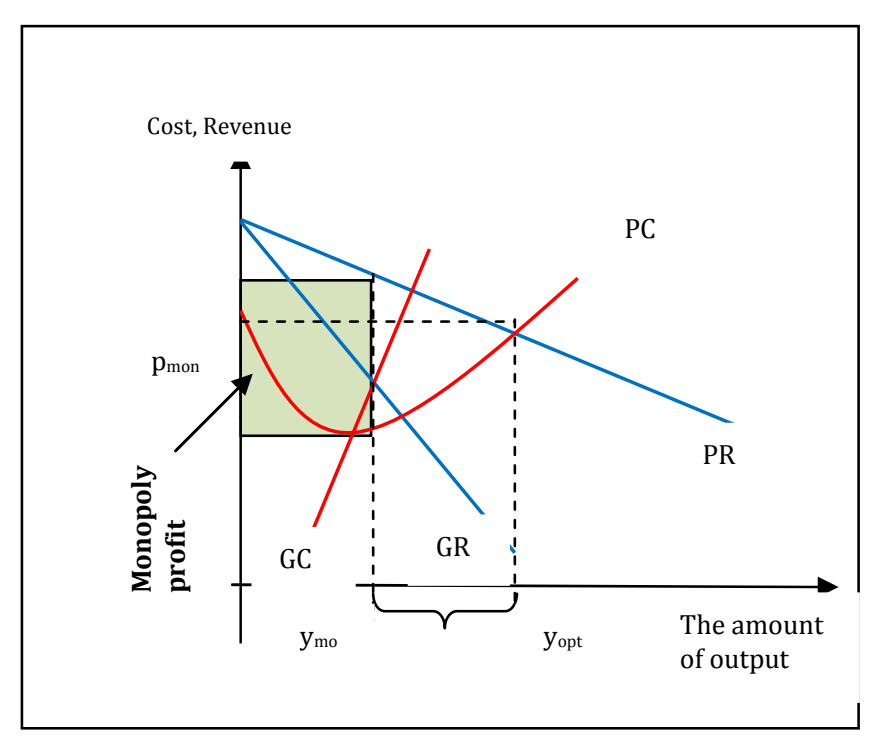

Figure 4.: The inefficiency of PC as a monopoly ${ }^{16}$

This characteristic the state must bear in mind when implement the reform of the state monopolies. Also, during the implementation of reforms of $\mathrm{PC}$, the state must also bear in mind the characteristics of the inefficiency of the work of monopoly. The inefficiencies of the monopoly can be viewed in the following negative consequences:

- inefficiencies in terms of the volume of the output; - inefficiencies in terms of the output prices;

- inefficiencies in terms of the engagement of inputs in the production of the output of the PC as a monopoly, and - the cost inefficiencies of the PC as a monopoly.

When a monopolist seeks to maximize its profit, i.e. if the monopolist is in a position to use its monopoly power, then it will produce the quantity of output $\left(\mathbf{y}_{\mathbf{m o n}}\right)$, which is on the level of intersection of the marginal revenue (GR) and the marginal cost (GC), determining the price ( $\mathbf{p}_{\text {mon }}$ ) which is above the fracture point of

\footnotetext{
${ }^{16}$ Ibid, page 326.
}

marginal sizes on the demand curve, thanks to its power, because it is the only one in the market. If the curves of incomes and expenses of a monopolist are as in the Figure 4, the maximum volume of production $\left(\mathbf{y}_{\text {opt }}\right)$ by price ( $\left.\mathbf{p}_{\text {opt }}\right)$ that monopolist can organize, and by doing so, it does not enter the loss zone, is found at the point where the average total income (PR) equals the overall average costs (PC). Based on the consideration of the volume of production $\left(\mathbf{y}_{\text {mon }}\right.$ and $\left.\mathbf{y}_{\text {opt }}\right)$ and the prices ( $\mathbf{p}_{\text {mon }}$ and $\left.\mathbf{p}_{\text {opt }}\right)$, all the inefficiencies of monopoly in terms of quantity and price can be seen.

Depending on the kind of the monopoly in question, there can be three scenarios of reforms of monopolized PC. In the first scenario, when the PC possesses a scarce resource, then the state must estimate whether to go into privatization or corporatization. If it chooses corporatization, it is necessary to achieve the minimum level of costs and determine the state level of the price of the output. The certain level of government prices for outputs should be on the level of prices marked as $\mathbf{p}_{\text {opt}}$, which for the society will provide the amount of output in the level $\mathbf{y}_{\text {opt }}$. If the state cannot achieve the targeted level of the total average cost to provide the quantity of output in the quantity $\mathbf{y}_{\text {opt }}$, then the state may choose to sell such a monopoly, but also with the prior verification of its strength ${ }^{17}$. The state verify its strenght in the sense whether it will have enough power to be able to regulate the price of a private monopoly which is at the level $\mathbf{p}_{\text {opt}}$, as well as conducting an analysis in the sense of assessing all negative effects, such as reducing the number of employees in the privatized public corporation and thus a

\footnotetext{
${ }^{17}$ State must weigh how powerful it is compared to the private partner that will buy PC and become a monopolist, especially when it comes to multinational companies. See more about this in the book: Stigliz J.E. (2009), "The success of globalization (New steps to a just world)," Algorithm Zagreb, p. 207-230.
} 
negative impact on the level of aggregate demand of the business environment, as well as whether such privatization of the monopolized PC is a big sale of rare national resources and what are the consequences for the safety and security of the state. If the negative consequences are greater than the positive ones, privatization should not be conducted and vice versa. Therefore, with the reform of PC as a monopoly of scarce resources it is necessary to prevent transformation of state monopoly into private one, with all its negative consequences.

In the second scenario, in the case that it is a legal monopoly, and that the state can provide outputs in the market, the same principles are valid as in the section 4 (PC in a competitive business environment). In particular, if there is a possibility for competition for the work of the PC, it is necessary as soon as possible to "free" such a legal monopoly PC from its monopolistic position and thus contribute to achievement of Pareto optimum in the economy.

And finally, according to the third scenario, in case of natural monopolies, the state must try primarily by corporatization of business activities to achieve the smallest possible minimum costs. Having in mind the specificity of natural monopolies, management must be competent enough to manage these inevitable/network monopolies. The mere competence of the management refers to:

- knowledge of economic laws, i.e. adequate education of potential managers;

- experience, i.e. references that the manager owns in his previous work experience in managing the similar companies;

- morality, if not ethics as part of the human personality.

The knowledge of economic laws is highly necessary, since by respecting the specificity of the competitive and monopolistic environment and by applying the known legalities at maximizing the objective function of PC, the planned economic values can be achieved. For example, natural monopolies have specific cost curves, i.e. their average total costs are very highly placed (Figure 5), the marginal costs are very low, so that in this case the cost efficiency could be achieved in order to cover the total average costs with the prices. Also, the above-mentioned characteristic of natural monopolies that their marginal costs are very low and almost constant, the application of the principle of equality limits (GR and GC) in the conditions of low demand cannot serve as the principle of maximizing the profits, because it may happen that the level of prices $\left(\mathrm{p}_{1}\right)$, which was projected on a curve of an average total demand, cannot cover costs in manufacturing the output of the PC, thus PC will be found in the zone of loss (Figure 5).

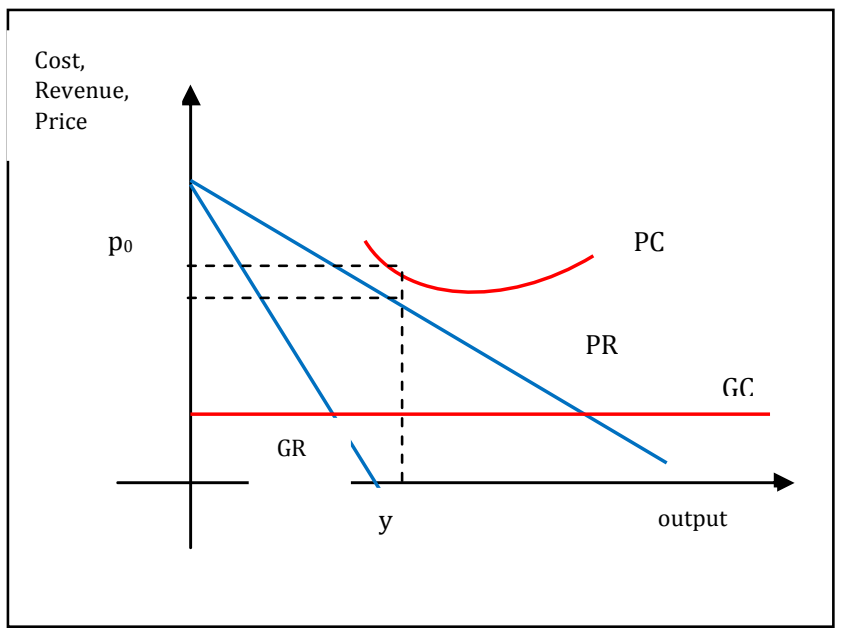

Figure 5.: PC as a natural monopoly ${ }^{18}$

Managers must also possess experience i.e. references that recommend them for the job. The principle of morality of the managers includes the previous two necessities in terms of competence, and these are knowledge and experience. It could be said that the basis of competence

\footnotetext{
${ }^{18}$ Ibid, p.333.
} 
of managers, who are recommended for work in the public sector, is their morality. From the principle of morality the selfassessment of managers should ensues in terms of his knowledge and experience. So, if a potential manager estimates that he does not have enough knowledge or experience, he should not even apply to the position of a manager of a public corporation. The principle of morality, which in the best possible way includes and explains the competence of managers of public companies, is not mere moralizing. It is, as a principle of competence, based on legal regulations of every country and is based on the general legal principle of "honesty, conscientiousness and due care" 19 .

If the Government cannot provide cost efficiency through corporatization as the reform of business operations of PC, then there is nothing else but privatization of natural monopolies. During the privatization of natural monopolies it is necessary for the Government to have enough strength and power to make an agreement with the owners of natural monopolies that in the least possible way adversely affects the level of social wellbeing of the state.

\section{Conclusion}

Having in mind the importance of PC for the national economy, it is necessary for the state to regulate all the imperfections of the market business environment through the companies that are in its possession or in any way subject to its influence. Also, having in mind their specificity in terms of a numerous restrictions which lead to the inefficiency of their business operations, it is necessary to take all the steps in their reform. The first essential step in the reform of the work of PC consists in corporatization of its business operations.

\footnotetext{
19 See more about this in the book: Vasiljevic M., (2012), "Trade Law", Faculty of Law, Belgrade, p.53-55.

Corporatization essentially includes increasing the freedom and responsibility of managers in managing the company, on the one hand, and, on the other, commercialization of the business in terms of directing all resources to the final user to make a public corporation more competitive, cost-effective and thus may contribute a maximum of social welfare of a society (both monetized and non monetized benefit).

If the reforms of the $\mathrm{PC}$ are conducted successfully, it can be expected that the PC will contribute to Pareto efficiency. In other words, the reformed public sector will contribute to the organization of production in the public sector at minimal cost (cost efficiency) and to the extent and structure of the output (production efficiency) that will be suitable to the preferences of the final consumer, which will result in maximizing their benefits, and all in accordance with their income limits (exchange-efficiency).

\section{References:}

1. A. Adler (2012), "Knowing the man," Dereta, Belgrade.

2. H.R.Varian (2010), "Microeconomics", Faculty of Economics, Belgrade.

3. M. Vasiljevic, (2012), "Trade law", Faculty of law, Belgrade.

4. Vukotic M., (1995), "Modern post", No. 1, JP PTT "Serbia" in Belgrade.

5. D. (1990) "Corporate Culture and economic Theory," in Alt, JA, Shepsle, K., 1990, Percpectives on Positive Political Economy, Cambridge UK: Cambridge University Press.

6. B. Krstić, Sekulić V., (2007), "Managing the Performance of the company", Faculty of Economics, Niš.

7. Krugman P., (2012), "End this depression.Immediately. "Heliks, Belgrade.

8. Mankiw NG, (2008)," Principles of Economics ", Faculty of Economics, Belgrade. 
9. Peltzman S., (1975),"The Effects of Automobile Safety Regulation", Journal of Political Economy, 83.

10. Rađenović B, N. Rodic, Rađenović M., (2010)," Communication ", High school of Technology, Šabac.

11. Rakić B., (2007), "The restructuring of public corporations owned by the Republic of Serbia", Faculty of Economics, Niš.

12. H.S. Rosen, T. Gayer (2011) "Public Finance", Economic University of Belgrade.
13. M. Stein, (2007), "Jung's map of the soul," Laguna, Belgrade.

14. Stiglitz J.E. (2004), "Public Economics", Economics University of Belgrade.

15. Stigliz J.E. (2009), "The success of globalization (New steps to a just world)," Algorithm Zagreb.

16. Friedman M., (1997), "Capitalism and Freedom, "Global, Novi Sad. 